\title{
Acidification and Nitrogen Eutrophication of Austrian Forest Soils
}

\author{
Robert Jandl, ${ }^{1}$ Stefan Smidt, ${ }^{1}$ Franz Mutsch, ${ }^{1}$ Alfred Fürst, ${ }^{1}$ \\ Harald Zechmeister, ${ }^{2}$ Heidi Bauer, ${ }^{3}$ and Thomas Dirnböck ${ }^{4}$ \\ ${ }^{1}$ Federal Research and Training Centre for Forests, Natural Hazards and Landscape, Seckendorff-Gudent-Weg 8, \\ 1131 Vienna, Austria \\ ${ }^{2}$ University of Vienna, Rennweg 14, 1030 Vienna, Austria \\ ${ }^{3}$ Division of Environmental and Process Analytics, Vienna University of Technology, Getreidemarkt 9/164, \\ 1061 Vienna, Austria \\ ${ }^{4}$ Environment Agency Austria, Spittelauer Lände 5, 1090 Vienna, Austria
}

Correspondence should be addressed to Robert Jandl, robert.jandl@bfw.gv.at

Received 2 December 2011; Revised 8 March 2012; Accepted 19 March 2012

Academic Editor: Larissa Macedo dos Santos

Copyright (c) 2012 Robert Jandl et al. This is an open access article distributed under the Creative Commons Attribution License, which permits unrestricted use, distribution, and reproduction in any medium, provided the original work is properly cited.

\begin{abstract}
We evaluated the effect of acidic deposition and nitrogen on Austrian forests soils. Until thirty years ago air pollution had led to soil acidification, and concerns on the future productivity of forests were raised. Elevated rates of nitrogen deposition were believed to cause nitrate leaching and imbalanced forest nutrition. We used data from a soil monitoring network to evaluate the trends and current status of the $\mathrm{pH}$ and the $\mathrm{C}: \mathrm{N}$ ratio of Austrian forest soils. Deposition measurements and nitrogen contents of Norway spruce needles and mosses were used to assess the nitrogen supply. The $\mathrm{pH}$ values of soils have increased because of decreasing proton depositions caused by reduction of emissions. The $\mathrm{C}: \mathrm{N}$ ratio of Austrian forest soils is widening. Despite high nitrogen deposition rates the increase in forest stand density and productivity has increased the nitrogen demand. The Austrian Bioindicator Grid shows that forest ecosystems are still deficient in nitrogen. Soils retain nitrogen efficiently, and nitrate leaching into the groundwater is presently not a large-scale problem. The decline of soil acidity and the deposition of nitrogen together with climate change effects will further increase the productivity of the forests until a limiting factor such as water scarcity becomes effective.
\end{abstract}

\section{Introduction}

Forests in central Europe provide manifold ecosystem services. Besides their function for wood production and protection, their soils represent an efficient filter and purification layer for water passing through, where they retain carbon and nitrogen. The maintenance of carbon stocks in soils contributes to the mitigation of climate change. In addition, forest soils buffer acidic deposition. Over the last three decades several factors have been identified which compromise the provision of these ecosystem services.

In the late 1970s, increasing evidence for forest decline arose [1]. The topic attracted a lot of public attention, followed by initiatives to reduce emissions and improve forest soils [2, 3]. In the mid 1980s, the nitrogen saturation hypothesis was brought up. Due to industrial processes the nitrogen input to forests has reached unprecedented levels [4-6]. It was expected that the release of ammonium into soils is harmful due to the proton generation during nitrification [7-9]. The formed nitrate is leached into the groundwater, and as a consequence base cations are lost. The nitrogen saturation hypothesis was expanded to nutrient imbalances; these occur as a consequence of high growth rates, caused by excess nitrogen, when other nutrients are in short supply [10]. Following the general trend, Austrian forest soils are affected by acidic deposition. Many sites are carrying a legacy of nutrient exploitation due to previous land-use practices. These sites were especially predisposed to acidification [11]. Soils formed on calcareous bedrock are less vulnerable. Historic forms of land use also have affected the nitrogen cycle. With respect to the nitrogen saturation hypothesis, it was expected that many forest soils 
were critically depleted in nitrogen in the past. These forest soils are, therefore, not easily oversaturated by incoming nitrogen, even when deposition loads exceed the actual nitrogen demand.

In Austria, the emission reduction between 1990 and 2009 amounted to $72 \%$ for $\mathrm{SO}_{2}$, but only to $3 \%$ for $\mathrm{NO}_{\mathrm{x}}$ and to $4 \%$ for $\mathrm{NH}_{3}$. Whereas mean annual $\mathrm{NO}_{\mathrm{x}}$-concentrations in Austrian nonurban areas have decreased over the last 20 years, the Austrian limit value $\left(30 \mu \mathrm{g} \mathrm{NO} \mathrm{x}^{-3}\right.$ according to BGBl. 298/2001) as well as critical loads (10 to $20 \mathrm{~kg} \mathrm{Nha}^{-1} \mathrm{yr}^{-1}$ depending on the respective ecosystem [12]) are often exceeded in the vicinity of roads [13, 14]. Critical loads are a reference system defining upper limits for the deposition of elements that can safely be processed within the ecosystem. The deposition of elements/substances becomes problematic when the capacity is exceeded. Critical loads are derived from the estimation of leaching rates from soils but also from the response of particularly vulnerable organisms such as lichens, mosses, and vascular plants [1518]. Air monitoring stations are irregularly installed and often placed where high pollution is expected. Alternative methods are necessary in order to provide a wider coverage of survey points. Bioindication with mosses is a useful tool to assess the nitrogen deposition [19-21].

(i) In this paper we show the long-term trend of soil $\mathrm{pH}$ in Austrian forest soils in order to evaluate the extent of the previous acidification and the recovery of forest soils as a consequence of the declining acidic deposition. We demonstrate the effect of the prolonged trend of nitrogen depositions on soil properties.

(ii) We evaluate the effect on the basis of soil parameters and of receptor organisms, that is, the nutrition of Austrian forest trees with nitrogen.

(iii) We compare the current deposition loads of protons and inorganic nitrogen with previously established critical loads. As a potential response to nitrogen enrichment, we present the temporal trend of the nitrogen nutrition of Austrian forests based on the Austrian Bioindicator Grid. As an indication for the spatial distribution of nitrogen supply, we present nitrogen concentrations in mosses.

(iv) Pathways of nitrogen in forest ecosystems-for example, leaching of nitrate into the groundwater-will be demonstrated by the example of two case studies.

\section{Materials and Methods}

2.1. Monitoring Networks. The evaluations are based on chemical data of soils and depositions and bioindication data from Austrian monitoring networks that are parts of several independently conducted transnational networks (Table 1).

2.2. Soils. The initial soil sampling was part of the ICPForests "Level I monitoring network" (http://www.icp-forests.net) and the second sampling was conducted within the
"BioSoil" project [22]. Data of $\mathrm{pH}$ values and $\mathrm{C}: \mathrm{N}$ ratios were selected from the comprehensive data pool and are discussed here. The data set comprises 39 sites on calcareous bedrock and 100 sites on silicatic bedrock.

2.3. Depositions. The Austrian deposition monitoring grid for forest ecosystem (ICP Forests programme) comprises 20 plots representing the dominant forest types in Austria. The sites are located in clean-air regions and reflect the background level of atmospheric deposition. Furthermore, 17 sample plots of the Federal deposition monitoring network, located mainly in rural areas, were included.

Locations and analytical procedures of the Austrian deposition monitoring grid are described in [23], those of the Federal deposition monitoring network by [24]. Among a series of ions the annual deposition rates of protons and total inorganic nitrogen (nitrate and ammonium) contents from wet deposition were evaluated.

2.4. Bioindication with Spruce and Pine Needles. Within the Austrian Bioindicator Grid (http://bioindikatornetz.at; BIN) the pollutant input and the nutrition status of forests are monitored. The BIN is organized on a regular grid and comprises the content of main nutrients and micronutrients in spruce and pine needles. Sampling was done annually in autumn. The nitrogen content of the foliage was used for this evaluation. According to [25] concentrations $<1.3 \%$ indicate nitrogen deficiency.

2.5. Bioindication with Mosses. The moss species Hylocomium splendens, Pleurozium schreberi, Hypnum cupressiforme, Abietinella abientina, and Scleropodium purum were sampled in 5-year intervals and analysed for nitrogen. These species have a similar morphological structure and a similar mechanism of nitrogen uptake. The objective of the moss analysis was to obtain a proxy for the long-term input of nitrogen when a comprehensive deposition monitoring system is not available. Here we use the content of nitrogen.

2.6. Case Studies at Intensive Investigating Plots. Input/output budgets of nitrogen were estimated for two long-term monitoring plots in Austria.

The site Zöbelboden belongs to the "Convention on Long-Range Transboundary Air Pollution” (CLRTAP)-Program and is located in the Northern limestone Alps (latitude: $47^{\circ} 50^{\prime} 30^{\prime \prime} \mathrm{N}$, longitude $14^{\circ} 26^{\prime} 30^{\prime \prime}$; http://www.umweltbundesamt.at/im). The bedrock is formed by dolomite, the altitude is $850-956 \mathrm{~m}$, the average annual temperature is $7.2^{\circ} \mathrm{C}$, and the annual rainfall ranges from 1500 to $1800 \mathrm{~mm}$. The mixed forests are dominated by Norway spruce (Picea abies) and beech (Fagus sylvatica). The site receives approx. $20 \mathrm{~kg} \mathrm{~N} \mathrm{ha}^{-1} \mathrm{yr}^{-1}$ and, depending on the forest type, between 21 and $27 \mathrm{~kg} \mathrm{Nha}^{-1} \mathrm{yr}^{-1}$ in the open field $[26,27]$.

The site Mühleggerköpfl is also located in the Northern Limestone Alps (latitude $47^{\circ} 34^{\prime} 50^{\prime \prime} \mathrm{N}$; longitude $11^{\circ} 38^{\prime} 21^{\prime \prime}$ E) at $910 \mathrm{~m}$ a.s.l. on a north-northeast facing slope. The mean annual air temperature and precipitation are $6.8^{\circ} \mathrm{C}$ 
TABLE 1: Austrian monitoring networks regarding the evaluation of soil acidification and nitrogen saturation, nitrogen deposition and bioindication of nitrogen deposition, and nutrition status. The location of the sample points is shown in Figures 5 and 6 .

\begin{tabular}{|c|c|c|c|c|}
\hline & Forest soils & Deposition & Spruce and pine needles & Mosses \\
\hline Project title & $\begin{array}{l}\text { Austrian forest soil } \\
\text { monitoring } \\
\text { system/BioSoil (EU) }\end{array}$ & $\begin{array}{l}\text { Austrian deposition monitoring } \\
\text { grid for forest ecosystem (ICP } \\
\text { Forests); Federal deposition } \\
\text { monitoring network }\end{array}$ & Austrian Bioindicator Grid & $\begin{array}{l}\text { Monitoring of atmospheric } \\
\text { pollution by mosses in Austria } \\
\text { (UNECE ICP monitoring } \\
\text { programme) }\end{array}$ \\
\hline Samplings & 1987 and 2007 & 1996-2009; 1984-2009 & 1983-2010 & 1991, 1995, 2000, 2005, 2010 \\
\hline Number of sites & 511 (1987); 139 (2007) & $20 / 14$ & 763 & 220 \\
\hline
\end{tabular}

and $1563 \mathrm{~mm}$, respectively. The experimental forest is 130years old and dominated by Norway spruce. The site receives approx $20 \mathrm{~kg} \mathrm{~N} \mathrm{ha}^{-1} \mathrm{yr}^{-1}[28,29]$.

2.7. Calculation of Critical Loads. The acidification of soils and the nitrogen saturation of forest ecosystems were calculated based on the Austrian forest inventory [30], the Austrian inventory of forest soils [31], and Corine 2006 land cover data [32]. The sulphur, nitrogen, and cation deposition rates were estimated from time series modelled by the sources $[33,34]$.

The soil data were evaluated with the SAS statistical package. For the change of soil $\mathrm{pH}$ and the $\mathrm{C}: \mathrm{N}$ ratio between the first and the second soil inventory, a pairwise comparison of means was done by a $t$-test. The data were stratified according to the geological substrate. The temporal trend of the proton and nitrogen input between 1983 and 2008 and the trend of the proportion of nitrogen deficient spruce and pine forests were evaluated by a linear regression.

\section{Results}

3.1. Soils. Austrian forest soils have consistently shown an increase of the $\mathrm{pH}$ during two decades (Figure 1). The strongest increase occurred in the organic surface layer $(\mathrm{FH}$ horizon) and the effect diminished with depth in the mineral soil. The variability is quite large. The deacidification of soils was stronger in soils on calcareous bedrock than on silicatic soils. The large error bars are explained by the small-scale spatial variability of soil properties. The temporal change of the $\mathrm{pH}$ is statistically significant in all depth layers of the calcareous soils and in the organic surface layer and the upper mineral soil $(0-10 \mathrm{~cm})$ of the silicatic soils. As a result of decreasing deposition of acidifying substances the critical loads for acidification are exceeded at only $0.6 \%$ of the Austrian forest area.

The $\mathrm{C}: \mathrm{N}$ ratio is an integrating indicator for the enrichment and the availability of nitrogen. A narrow $C: N$ ratio indicates a high availability of nitrogen with several consequences such as an improved nitrogen supply for plants and a higher soil microbial activity. According to Figure 2, the $\mathrm{C}: \mathrm{N}$ ratio was slightly widening during the last 20 years. The effect is strongest in the forest floor material. Soils did not respond differently among the 2 geological substrates. Contrary to the soil $\mathrm{pH}$, the change in the $\mathrm{C}: \mathrm{N}$ ratio is not statistically significant, although the ratio has become wider.

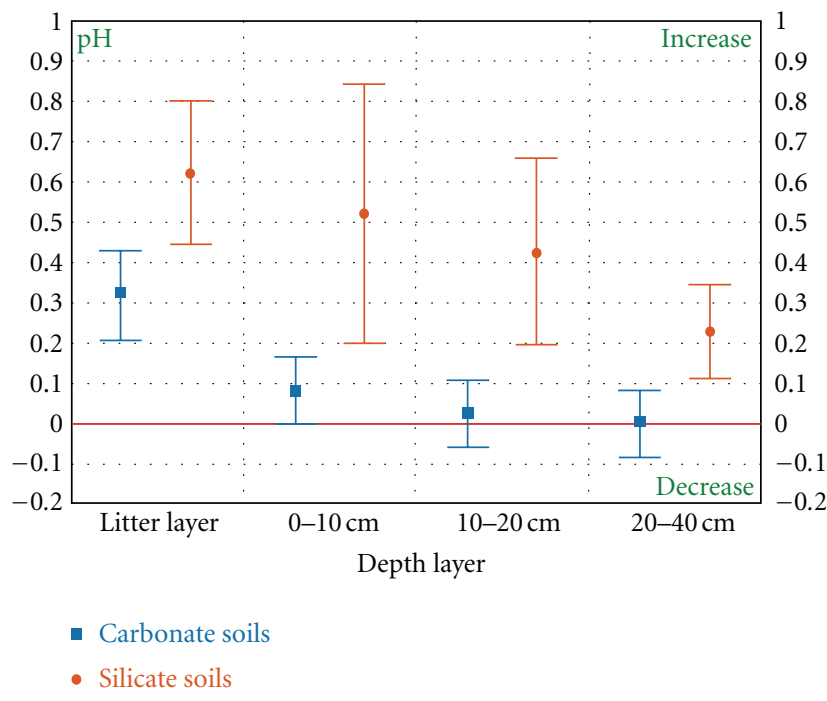

FIGURE 1: pH change of Austrian forest soils between 1987 (old) and 2007 (new) for different soil depths, differentiated for carbonatefree (silicatic, left bars) and carbonate-influenced (right bars) soils.

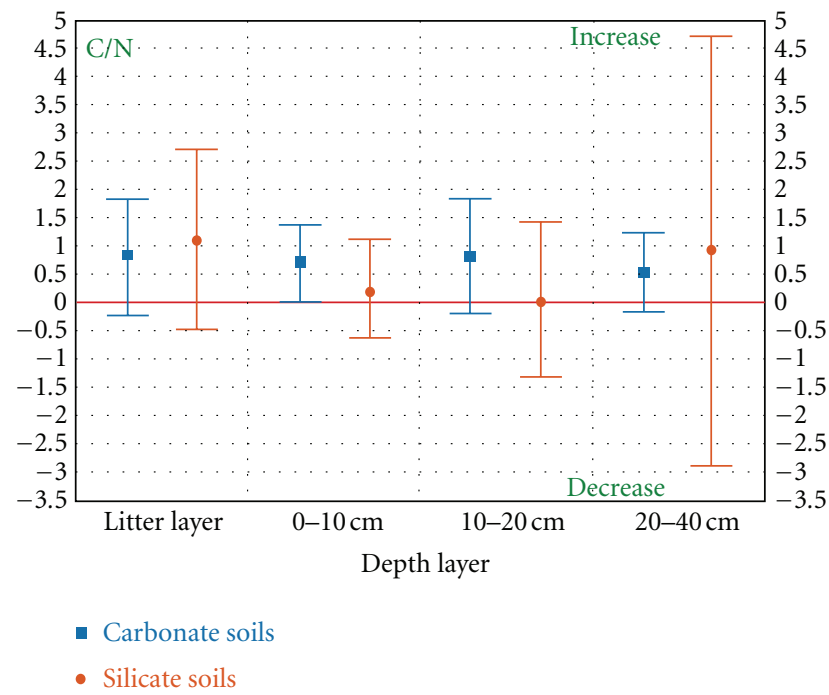

Figure 2: Change of the $\mathrm{C} / \mathrm{N}$ ratio of Austrian forest soils between 1987 (old) and 2007 (new) for different soil depths, differentiated for carbonate-free (silicatic, left bars) and carbonate-influenced (right bars) soils. 


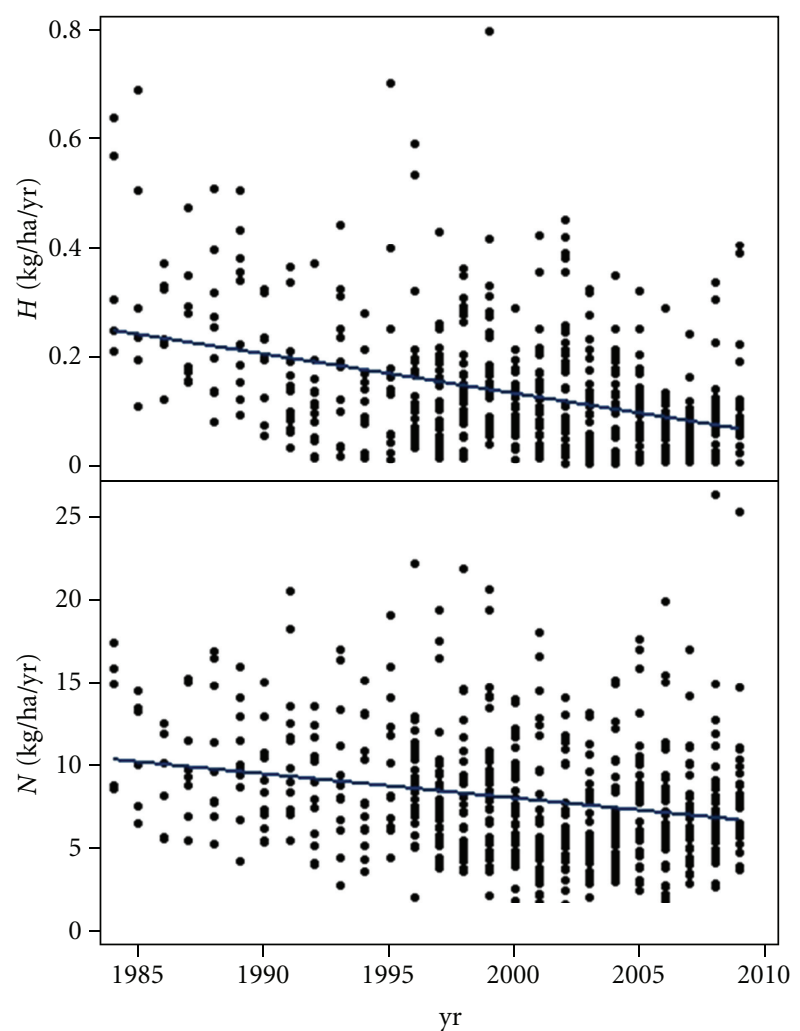

FIGURE 3: Annual input of protons (above) and inorganic nitrogen (below) in Austria.

3.2. Depositions. Long-term measurements of the wet proton deposition (free acidity) in Austria show a general decrease over time. Between 1984 and 1993s the input of protons decreased substantially (between 39 and 99\%) at five sites situated at the northern Alpine rim and in the inner Alpine area [24]. The highest inputs—up to $0.7 \mathrm{~kg} \mathrm{H}^{+} \mathrm{ha}^{-1} \mathrm{yr}^{-1}$ were measured in the eastern part of Austria. The chemical quality of the rain water varies widely in Austria depending on the distance to emitters, and their exposure to imported air pollutants. In general, the pollutant loads correspond to the precipitation pattern so that higher deposition is particularly found at the northern slopes of the Alps and to some extent in southern Carinthia. The mean deposition of protons is $134 \mathrm{~g} \mathrm{H}^{+} \mathrm{ha}^{-1} \mathrm{yr}^{-1}$ and decreases significantly by $7 \mathrm{~g} \mathrm{H}^{+} \mathrm{ha}^{-1} \mathrm{yr}^{-1}$ from 1984 to $2009(P<0.001$; Figure 3, Table 2).

Nitrogen is entering the ecosystem as deposition of ammonium, nitrate, and organic nitrogen. The average total input of inorganic nitrogen is approximately $8 \mathrm{~kg} \mathrm{ha}^{-1} \mathrm{yr}^{-1}$. Figure 3 illustrates the considerable variation of nitrogen deposition, caused by the heterogeneity of sites. The variability is caused by the proximity of sites with high precipitation rates and high local emission and sites in the rain shade of mountain ranges that receive very little deposition. During the observation period between 1996 and 2009 the nitrogen input slightly, but significantly decreased. The highest inorganic nitrogen inputs (up to $22 \mathrm{~kg} \mathrm{ha}^{-1} \mathrm{yr}^{-1}$ )
TABle 2: Mean annual deposition rates of protons and nitrogen, mean annual changes, and significance of the changes at Austria measurement sites. The sites are irregularly distributed.

\begin{tabular}{lcccc}
\hline Element & $\begin{array}{c}\text { Mean annual } \\
\text { deposition } \\
{\left[\mathrm{kg} \mathrm{ha}^{-1} \mathrm{yr}^{-1}\right]}\end{array}$ & $\begin{array}{c}\text { Mean annual } \\
\text { change }[\mathrm{kg} \\
\left.\mathrm{ha}^{-1}\right]\end{array}$ & $\begin{array}{c}\text { Significance } \\
\text { of change }\end{array}$ & $\begin{array}{c}\text { Number } \\
\text { of } \\
\text { samples }\end{array}$ \\
\hline $\mathrm{H}$ & 0.134 & -0.007 & $* * *$ & 602 \\
$\mathrm{~N}$ (inorganic) & 8.056 & -0.146 & $* * *$ & 603 \\
\hline
\end{tabular}

TABle 3: critical loads (CL) for acidification $\left(\mathrm{kg} \mathrm{ha}^{-1} \mathrm{yr}^{-1}\right)$ and eutrophication $\left(\mathrm{kg} \mathrm{ha}^{-1} \mathrm{yr}^{-1}\right)$ of the Austrian forested area. CL$\operatorname{acid}_{\max }(\mathrm{S})$ : critical load of $\mathrm{S}$ assuming an exclusion of $\mathrm{N}$; CL-acid $\mathrm{max}_{\text {max }}$ $(\mathrm{N})$ : critical load of $\mathrm{N}$ assuming an exclusion of S; CL-eut ${ }_{\text {nut }}(\mathrm{N})$ : CL for eutrophication according to the mass balance; CL-eut ${ }_{\text {emp }}(\mathrm{N})$ : empirical CL for eutrophication for Austrian forest types according to [26] ECE (2010).

\begin{tabular}{lccc}
\hline & 25th percentile & median & 75th percentile \\
\hline CL-acid $_{\max }(\mathrm{S})$ & 2.384 & 2.776 & 6.242 \\
CL-acid $_{\max }(\mathrm{N})$ & 4.125 & 4.982 & 9.891 \\
CL-eut $_{\text {nut }}(\mathrm{N})$ & 10.1 & 11.0 & 11.9 \\
CL-eut $_{\text {emp }}$ (N) & & $10-20$ &
\end{tabular}

CL-acid

Percent area with an exceedance of the CL

CL-eut

$0.6 \%$

$94 \%$

were observed in the northern Alpine rim and in the eastern part of Austria, the lowest in the Inner Alps.

The critical loads for nitrogen eutrophication are exceeded at some sites. Average critical loads for acidification are relatively high due to carbonate bedrock in many Austria areas. Exceedance only occurred at $0.6 \%$ of the Austrian forest area. Critical loads for eutrophication based on mass balance are around $11 \mathrm{~kg} \mathrm{ha}^{-1} \mathrm{yr}^{-1}$. Nitrogen immobilisation increases with altitude, whereas losses by nitrogen leaching decrease with altitude. The critical loads for nitrogen vary between 10 and $20 \mathrm{~kg} \mathrm{Nha}^{-1} \mathrm{yr}^{-1}$ over the Austrian territory. In total, $94 \%$ of the Austrian forest area features a deposition exceeding the critical load for eutrophication. The exceedance is $4.1 \mathrm{~kg} \mathrm{~N} \mathrm{ha}^{-1} \mathrm{yr}^{-1}$ on average and highest in the northern part of the Alps and in eastern Austria (Table 3).

3.3. Bioindication with Spruce and Pine Needles. The trend of decreasing nitrogen availability in soils, indicated by the $\mathrm{C}: \mathrm{N}$ ratios, corresponds to the nitrogen deficiency in needles that was revealed by the Austrian Bioindicator Grid (Figure 4). According to the threshold values of $1.3 \% \mathrm{~N}$, the area of nitrogen deficient sites in Austrian forests has increased since the early 1980s. By contrast, the nitrogen supply has been diminished and no evidence for nitrogen enrichment is given based on nitrogen contents of spruce needles.

The geographic distribution of the nutrition status has totally changed during the last 30 years (Figure 5). Areas in the north and southeast of the country have been well supplied with nitrogen in the past and suffer currently from 


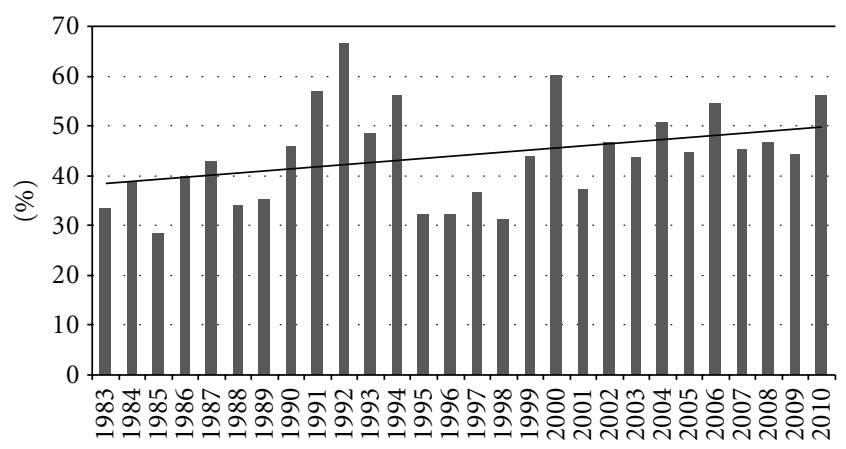

FIgURE 4: Trend of the proportion of nitrogen deficient sites of Norway spruce and Scots pine in Austrian forests from 1983 to 2010 (Austrian Bioindicator Grid).

nitrogen deficiency. In the Central Alps the nitrogen supply has declined in the last 25 years.

3.4. Mosses. The distribution of the nitrogen content of mosses can be taken as a surrogate for nitrogen deposition in areas not covered directly by trees or shrubs. As shown in Figure 6, nitrogen deposition has been elevated in densely populated areas, especially where the density of car traffic is high, where nitrogen was mainly deposited as nitrate. Furthermore, higher concentrations in the northern part of Austria are caused by intensive agriculture (e.g., cattle raising). In these areas ammonium was the main emission source [21]. The nitrogen content of mosses in the mountain regions is substantially lower.

3.5. Case Studies at Intensive Investigating Plots. Concerns on the nitrogen saturation of forests invoked the implementation of several case studies where the nitrate leaching from forest ecosystems was quantified. At the two long-term monitoring sites Zöbelboden and Mühleggerköpfl precipitation is high, so that even at low nitrogen concentrations in the rain deposition load is considerable. These sites are characterized either by mature spruce-dominated forests or mixed coniferdeciduous forests and a mosaic of deep chromic Cambisols and shallow rendzic Leptosols, developed from the underlying dolomite gravel. We assessed whether the soils were currently capable to retain the incoming nitrogen or whether they released nitrate into the karst aquifer. A repeated soil inventory at Zöbelboden had indicated a slight increase in the nitrogen pool of the organic surface layer and botanists observed an increase in the coverage of nitrogen demanding herbaceous plants and bryophytes $[35,36]$. An estimation of the nitrogen losses by leaching showed no indication for nitrogen saturation. The nitrogen release in the aqueous phase, though quite high, was still dominated by specific events such as strong snow melt, high amounts of litterfall due to drought in the year 2003, or an increase of nitrogen availability after a bark beetle attack that had taken out several trees and left some of the available nitrogen unutilized [36]. As a result, leaching of inorganic nitrogen can even rise to $20 \mathrm{~kg} \mathrm{Nha}^{-1} \mathrm{yr}^{-1}$. The overall magnitude of nitrogen leaching differs substantially between forests and soil types. The site in Tyrol also shows a remarkable nitrogen retention capacity. In all the years the nitrogen release in the aqueous phase was lower than the nitrogen input from deposition [37].

\section{Discussion}

The consistent increase of the soil $\mathrm{pH}$ within the last 20 years gives evidence of strong changes in the Austrian forest ecosystems (Figure 1). The alkalinisation of forest soils has also been shown consistently in Europe [38, 39]. The decrease of soil acidity can partially be attributed to the decrease of $\mathrm{SO}_{2}$ and $\mathrm{NO}_{\mathrm{x}}$ emissions which diminished stress caused by acid deposition. However, effects of reduced emissions from industry are superimposed by the long-term recovery of soils from negative impacts of former land use practices [40]. Before mineral fertilisers became available for low prices, shortly after World War II, forests commonly served as a source for organic material and nutrients for agriculture and have, therefore, been degraded [41]. During the last 60 years, a recovery of forest soils has been observed in central Europe [42]. Therefore, the increase in soil pH is a combined response to both reduction of emissions from industrial sources and change in land use intensity.

The widening of the soil $\mathrm{C}: \mathrm{N}$ ratio is an indication for a decreasing nitrogen availability in Austrian forest soils (Figure 2). Air pollution due to both imported long-range transport and local nitrogen emissions, caused considerably higher nitrogen deposition compared to the preindustrial amounts. Currently, the emissions are slightly declining. In addition the discontinuation of litter raking ensures that no longer large quantities of nitrogen are removed from forest soils. It was hypothesized that forest soils were approaching nitrogen saturation. However, we did not find evidence that forest soils were accumulating nitrogen. A major reason is the accentuated increase of the productivity of central European forests. The differentiation of simultaneous effects such as nitrogen enrichment, $\mathrm{CO}_{2}$ fertilisation, changed forest management and elongation of the growing season revealed that nitrogen was the most important factor [4345]. Moreover, the adverse effects of acidic deposition $\left(\mathrm{SO}_{2}\right.$, $\mathrm{NO}_{\mathrm{x}}$ ) are no longer effective on a large scale. Increased growth rates of forests demand higher nitrogen supply from soils. The high productivity of forests is paralleled by lower nitrogen contents of the leaves and can only be supported by the effective utilization of the soil nitrogen pool, as indicated by the increase in nitrogen deficiency and the wider $\mathrm{C}: \mathrm{N}$ ratio (Figures 2 and 4). Other factors such as increased soil organic matter decomposition due to higher temperatures and higher soil $\mathrm{pH}$ values [46] and improved types of forest management are probably less important.

The change of the proton deposition is remarkable (Figure 3). The concern for the quality of the environment led to legal measures obligating industry to efficiently reduce $\mathrm{SO}_{2}$ emissions. The implementation was successful due to the well-defined industrial sources of $\mathrm{SO}_{2}$. The reduction of nitrogen oxide emissions in order to counteract the effect 




FIgURE 5: Nitrogen content of moss tissue at 220 sampling sites in Austria following a method established within the framework of UNECE/ICP vegetation. Dots represent measured concentrations in mosses; grey colours were derived from interpolation by means of ordinary kriging.

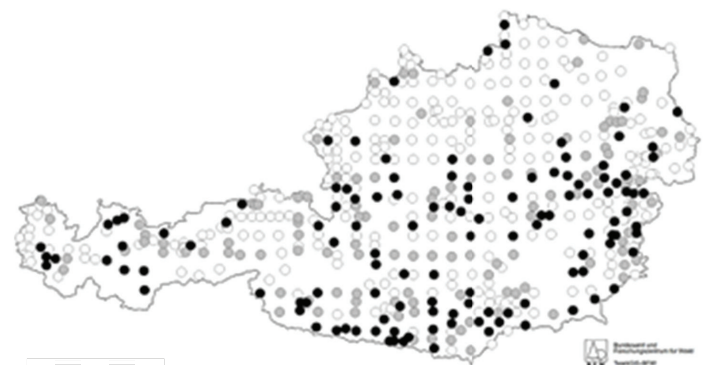

Bioindicator Grid 1983-1987 Nitrogen deficiency

- In 0 till 1 year

- In 2 till 3 years

- In 4 till 5 years

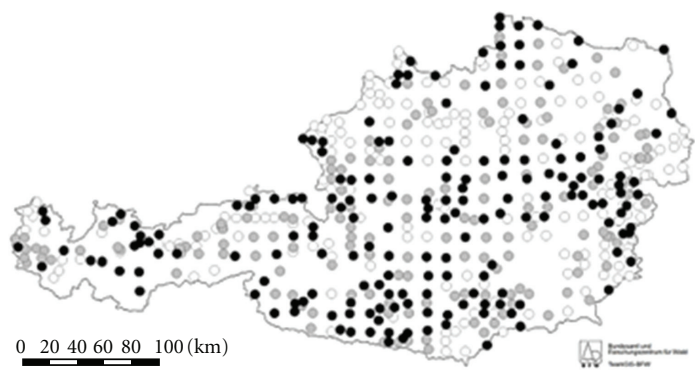

Bioindicator Grid 2006-2010 Nitrogen deficiency

- In 0 till 1 year

- In 2 till 3 years

- In 4 till 5 years

(a)

(b)

FIGURE 6: Nitrogen nutrition of Austrian forest, based on the amounts of nitrogen deficiency in the period 1983-1987 (a) and 2006-2010 (b).

of nitrogen saturation was more difficult as the sources of these nitrogen compounds are more diffuse. The increase of road traffic density led to increased nitrogen emission rates that almost compensated the emission reductions in other sectors. Taking into account that $\mathrm{SO}_{2}$ emissions have declined and that $\mathrm{NO}_{\mathrm{x}}$ concentrations in the atmosphere did not markedly decrease we conclude that sulphuric acid is now of minor relevance for soil acidification, whereas nitric acid still supplies protons. Further sources of acidification are nitrification caused by high rates of $\mathrm{NH}_{4}$ deposition.

The decline of the nitrogen nutrition of forests (Figures 4 and 5) is explained by observed forest management dynamics during the last decades. Forest ecosystems in central Europe have been used less exploitative for several decades. Being aware that closed nutrient cycles are relevant for ecosystems, their maintenance has been fully integrated into the concepts of sustainable forest management. The nitrogen demand has more strongly increased than the nitrogen supply in Austria due to afforestation of marginal agricultural land and the extended area of young forests with a high nitrogen demand [47]. Moreover, stand densities are increasing due to economic constraints in terms of thinning operations. Political incentives towards the expansion of the production of renewable energy are expected to increase the demand 
for wood biomass in the future. A consequence would be the increase of the management intensity and the intensified mobilisation of this resource $[17,48]$.

Trees are investing additional nitrogen in an increase of the needle biomass in order to achieve high productivity rates. The supply and the availability of nitrogen over an prolonged growing season as a consequence of rising temperatures reduces the nitrogen content in photosynthetically active tissues. In conclusion, the increase of nitrogen availability is not invested in nitrogen-enriched needles and leaves, but in an expansion of the tree. Fertilisation experiments demonstrated that nitrogen amendments led only transiently to higher concentrations in leaves, but primarily replenished the previously exhausted soil nitrogen pool [49].

The findings from needle analyses were confirmed by moss analyses. In contrast to needles, for mosses the atmosphere is the main nitrogen source. The analyses indicate that the nitrogen content of mosses is a useful integrating parameter for the long-term supply of nitrogen from atmospheric sources [21,35].

The case studies of nitrogen leaching did not give any indication that the forest soils would lose their ability to retain nitrogen. The nitrogen saturation hypothesis according to [9] is still considered to be valid. However, under natural conditions it could not be demonstrated that moderately elevated nitrogen depositions led to continuous and prolonged nitrogen leaching. Furthermore, metaanalyses of long-term studies revealed a number of factors as prerequisites for losses due to nitrate leaching in addition to deposition [50]. In a comprehensive review [51], it was demonstrated that nitrogen leaching is connected with ecosystem disturbances. However, it is difficult to identify the nitrogen enrichment of undisturbed forests, because the excess nitrogen of a quantity of several kilograms per ha and year dissipates in the large pool of several tons per ha.

Although model based mapping of critical loads has its weaknesses [52], the widespread exceedance in Austria and elsewhere should attract more interest [53]. Global warming prolongs the growing season and increases the productivity of forests. Consequently, the demand for nitrogen is expected to increase. For regions with limited nitrogen supply, a "progressive nitrogen limitation" is expected [54, 55]. Global warming might, therefore, mitigate the problem of nitrogen saturation of forest ecosystems.

Forest disturbances are predicted to increase and have the potential to mobilize reasonable amounts of $\mathrm{N}$ as shown by our case studies and elsewhere [27]. The uncertainty regarding the identification of critical input rates cannot be a justification to ignore the challenge. From the viewpoint of the chemical quality of water from forest ecosystems, it is important to know the limit of nitrogen retention capacity.

\section{Conclusions}

(i) In Austria, soils formed on noncalcareous bedrock are recovering from previous acidification due to the release from exploitative forms of forest management during centuries and acidic deposition in recent history.

(ii) The $\mathrm{C}: \mathrm{N}$ ratio of Austrian forest soils is widening, despite a higher availability and quicker turnover of nitrogen. The higher productivity of forests and changes of the management intensity increase the nitrogen demand.

(iii) Nitrogen saturation is conceptually well understood but difficult to identify on the plot level when nitrogen deposition is not massively exceeding critical loads.

(iv) The nitrogen budgets of two intensive monitoring plots have shown that soils can retain high amounts of nitrogen, even when the input rate is exceeding the demand by plants. Nitrate leaching is presently not a large-scale problem but could become one in the future when nitrogen emission is not reduced.

(v) The supply with nitrogen is worst among the main nutrients nitrogen in Austrian forests.

(vi) Mosses are useful bioindicators for atmospheric nitrogen deposition as they are integrating the nitrogen depositions of several years. Nitrogen concentration in well-defined moss species can be taken as proxies for nitrogen deposition in the respective growth area.

\section{References}

[1] J. O. Reuss and D. W. Johnson, "Acid deposition and the acidification of soils and waters," in Ecological Studies, vol. 59, Springer, 1986.

[2] R. Hüttl, "Forest fertilisation: results from Germany, France and the nordic countries," in Proceedings of the International Fertiliser Society, vol. 250, p. 40, 1986.

[3] R. Jandl, G. Glatzel, K. Katzensteiner, and O. Eckmüllner, "Amelioration of magnesium deficiency in a Norway spruce stand (Picea abies) with calcined magnesite," Water, Air, and Soil Pollution, vol. 125, no. 1-4, pp. 1-17, 2001.

[4] P. M. Vitousek, J. D. Aber, R. W. Howarth et al., "Human alteration of the global nitrogen cycle: sources and consequences," Ecological Applications, vol. 7, no. 3, pp. 737-750, 1997.

[5] J. W. Erisman, "The European nitrogen problem in a global perspective," in The European Nitrogen Assessment, chapter 2, pp. 9-31, Cambridge University Press, 2011.

[6] M. A. Sutton, O. Oenema, J. W. Erisman, A. Leip, H. Van Grinsven, and W. Winiwarter, "Too much of a good thing," Nature, vol. 472, no. 7342, pp. 159-161, 2011.

[7] B. Nihlgard, "The ammonium hypothesis. An additional explanation to the forest dieback in Europe," Ambio, vol. 14, no. 1, pp. 2-8, 1985.

[8] J. D. Aber, "Nitrogen cycling and nitrogen saturation in temperate forest ecosystems," Trends in Ecology and Evolution, vol. 7, no. 7, pp. 220-224, 1992.

[9] J. Aber, W. McDowell, K. Nadelhoffer et al., "Nitrogen saturation in temperate forest ecosystems: hypotheses revisited," BioScience, vol. 48, no. 11, pp. 921-934, 1998.

[10] H. Van Oene, "Acid deposition and forest nutrient imbalances: a modeling approach," Water, Air, and Soil Pollution, vol. 63, no. 1-2, pp. 33-50, 1992. 
[11] R. Jandl, C. Alewell, and J. Prietzel, "Calcium loss in Central European forest soils," Soil Science Society of America Journal, vol. 68, no. 2, pp. 588-595, 2004.

[12] World Health Organization, Air Quality Guidelines for Europe, European Series No. 91, WHO Regional Publications, 2nd edition, 2000.

[13] S. Smidt and E. Obersteiner, "10 Jahre Depositionsmessung im Rahmen des europäischen Waldschadensmonitorings," Centralblatt für das Gesamte Forstwesen, vol. 124, no. 2, pp. 83 104, 2007.

[14] S. Smidt, W. Spangl, and C. Nagl, "Trends von Schadstoffeinträgen in österreichischen Waldgebieten," Centralblatt für das Gesamte Forstwesen, vol. 127, no. 1, pp. 1-24, 2010.

[15] D. A. Burns, T. Blett, R. Haeuber, and L. H. Pardo, "Critical loads as a policy tool for protecting ecosystems from the effects of air pollutants," Frontiers in Ecology and the Environment, vol. 6, no. 3, pp. 156-159, 2008.

[16] ECE, "Empirical critical loads and dose-response relationships," 20th Session, Working Group on Effects Executive Body for the Convention on Long-range Transboundary Air Pollution, Economic Commission for Europe, Geneva, Switzerland, 2010.

[17] M. E. Fenn, S. Jovan, F. Yuan, L. Geiser, T. Meixner, and B. S. Gimeno, "Empirical and simulated critical loads for nitrogen deposition in California mixed conifer forests," Environmental Pollution, vol. 155, no. 3, pp. 492-511, 2008.

[18] G. Velthof, "Nitrogen as a threat to European soil quality," in The European Nitrogen Assessment, vol. 21, pp. 495-509, Cambridge University Press, 2011.

[19] M. E. Conti and G. Cecchetti, "Biological monitoring: lichens as bioindicators of air pollution assessment-a review," Environmental Pollution, vol. 114, no. 3, pp. 471-492, 2001.

[20] B. A. Markert, A. M. Breure, and H. G. Zechmeister, Eds., Bioindicators and Biomonitors. Principles, Concepts and Applications, Elsevier, Amsterdam, The Netherlands, 2003.

[21] H. G. Zechmeister, A. Richter, S. Smidt et al., "Total nitrogen content and $\delta^{15} \mathrm{~N}$ signatures in moss tissue: indicative value for nitrogen deposition patterns and source allocation on a nationwide scale," Environmental Science and Technology, vol. 42, no. 23, pp. 8661-8667, 2008.

[22] R. Hiederer and T. Durrant, "Evaluation of BioSoil demonstration project-preliminary data analysis," EUR 24258 EN, Office for Official Publications of the European Communities, Luxembourg, 2010.

[23] S. Smidt, "10 years of deposition monitoring within the European forest monitoring programme," BFW-Berichte, vol. 138, 2007 (German).

[24] H. Puxbaum, V. Simeonov, and M. F. Kalina, "Ten years trends (1984-1993) in the precipitation chemistry in Central Austria," Atmospheric Environment, vol. 32, no. 2, pp. 193-202, 1998.

[25] R. Hüttl, "Forest fertilisation: results from Germany, France and the nordic countries," in Proceedings of the International Fertiliser Society, vol. 250, p. 40, 1986.

[26] J. Kobler, W. J. Fitz, T. Dirnböck, and M. Mirtl, "Soil type affects migration pattern of airborne $\mathrm{Pb}$ and $\mathrm{Cd}$ under a spruce-beech forest of the UN-ECE integrated monitoring site Zöbelboden, Austria," Environmental Pollution, vol. 158, no. 3, pp. 849-854, 2010.

[27] G. Jost, T. Dirnböck, M. T. Grabner, and M. Mirtl, "Nitrogen leaching of two forest ecosystems in a Karst Watershed," Water, Air and Soil Pollution, vol. 218, no. 1, pp. 633-649, 2011.
[28] S. Smidt, "Nitrogen fluxes in the Tyrolean Limestone Alps," Environmental Science and Pollution Research International, no. 2, p. 52, 2002.

[29] A. Schindlbacher, S. Zechmeister-Boltenstern, and R. Jandl, "Carbon losses due to soil warming: do autotrophic and heterotrophic soil respiration respond equally?" Global Change Biology, vol. 15, no. 4, pp. 901-913, 2009.

[30] K. Schieler and K. Schadauer, The Austrian Forest Inventory 1992-96, Austrian Federal Office and Research Centre for Forests, Vienna, Austria, 2011.

[31] Forstliche Bundesversuchsanstalt, "Austrian forest soil inventory," in Mitteilungen der Forstlichen Bundesversuchsanstalt, vol. 168, Wien, 1992.

[32] CLC, “Corine Land Cover 2006," EEA, Copenhagen, Denmark, 2010, http://sia.eionet.europa.eu/CLC2006.

[33] EMEP, "EMEP/MSC-W modelled air concentrations and depositions," European Monitoring and Evaluation Programme, 2009, http://webdab.emep.int/Unified_Model_Results/.

[34] M. van Loon, L. Tarrason, and M. Posch, "Modelling Base Cations in Europe," EMEP/MSC-W \& CCE Note x/2005-Draft 1.2., 2005.

[35] H. G. Zechmeister, T. Dirnböck, K. Hülber, and M. Mirtl, "Assessing airborne pollution effects on bryophytes-lessons learned through long-term integrated monitoring in Austria," Environmental Pollution, vol. 147, no. 3, pp. 696-705, 2007.

[36] K. Hülber, T. Dirnböck, I. Kleinbauer et al., "Long-term impacts of nitrogen and sulphur deposition on forest floor vegetation in the Northern limestone Alps, Austria," Applied Vegetation Science, vol. 11, no. 3, pp. 395-404, 2008.

[37] R. Jandl, F. Herman, S. Smidt et al., "Modelling of nitrogen dynamics in an Alpine forest ecosystem on calcareous soils: a scenario-based risk assessment under changing environmental conditions," Environmental Pollution, vol. 155, pp. 512-516, 2008.

[38] D. Arrouays, P. H. Bellamy, and K. Paustian, "Soil inventory and monitoring. Current issues and gaps," European Journal of Soil Science, vol. 60, no. 5, pp. 721-722, 2009.

[39] G. J. D. Kirk, P. H. Bellamy, and R. M. Lark, "Changes in soil $\mathrm{pH}$ across England and Wales in response to decreased acid deposition," Global Change Biology, vol. 16, no. 11, pp. 31113119, 2010.

[40] R. Jandl, F. Starlinger, M. Englisch, E. Herzberger, and E. Johann, "Long-term effects of a forest amelioration experiment," Canadian Journal of Forest Research, vol. 32, no. 1, pp. 120-128, 2002.

[41] J. Hofmeister, F. Oulehle, P. Krám, and J. Hruška, "Loss of nutrients due to litter raking compared to the effect of acidic deposition in two spruce stands, Czech Republic," Biogeochemistry, vol. 88, no. 2, pp. 139-151, 2008.

[42] J. Prietzel, E. Kolb, and K. E. Rehfuess, "Long-term monitoring of previously litter-raked pine forest sites in the province Oberpfalz: changes in soil chemical properties and of forest nutrition," Forstwissenschaftliches Centralblatt, vol. 116, pp. 269-290, 1997 (German).

[43] K. Schadauer, "Growth trends in Austria," in Growth Trends in European Forests, H. Spiecker, K. Mielikäinen, M. Köhl, and J. Skovsgaard, Eds., pp. 275-289, Springer, 1996.

[44] H. Spiecker, K. Mielikäinen, M. Köhl, and J. Skovsgaard, "Growth Trends in Europe-Studies from 12 countries," in Growth Trends in European Forests, vol. 5, pp. 275-289, Springer, 1996. 
[45] M. van Oijen and R. Jandl, "Nitrogen fluxes in two Norway spruce stands in Austria: an analysis by means of process-based modeling," Austrian Journal of Forest Research, vol. 121, pp. 167-182, 2004.

[46] N. P. Lamersdorf and W. Borken, "Clean rain promotes fine root growth and soil respiration in a Norway spruce forest," Global Change Biology, vol. 10, no. 8, pp. 1351-1362, 2004.

[47] W. Russ, "Mehr Wald in Österreich," BFW-Praxisinformation, vol. 24, pp. 3-5, 2011.

[48] P. Fairley, "Introduction: next generation biofuels," Nature, vol. 474, no. 7352, pp. S2-S5, 2011.

[49] C. Huber, W. Weis, and A. Göttlein, “Tree nutrition of Norway spruce as modified by liming and experimental acidification at the Höglwald site, Germany, from 1982 to 2004," Annals of Forest Science, vol. 63, no. 8, pp. 861-869, 2006.

[50] J. J. Rothwell, M. N. Futter, and N. B. Dise, "A classification and regression tree model of controls on dissolved inorganic nitrogen leaching from European forests," Environmental Pollution, vol. 156, no. 2, pp. 544-552, 2008.

[51] H. Van Miegroet and D. W. Johnson, "Feedbacks and synergism among biogeochemistry, basic ecology, and forest soil science," Forest Ecology and Management, vol. 258, no. 10, pp. 2214-2223, 2009.

[52] R. A. Skeffington, "Quantifying uncertainty in critical loads. A literature review," Water, Air, and Soil Pollution, vol. 169, no. 1-4, pp. 3-24, 2006.

[53] M. Lorenz, H. D. Nagel, O. Granke, and P. Kraft, "Critical loads and their exceedances at intensive forest monitoring sites in Europe," Environmental Pollution, vol. 155, no. 3, pp. 426-435, 2008.

[54] Y. Luo, B. Su, W. S. Currie et al., "Progressive nitrogen limitation of ecosystem responses to rising atmospheric carbon dioxide," BioScience, vol. 54, no. 8, pp. 731-739, 2004.

[55] D. W. Johnson, "Progressive N limitation in forests: review and implications for long-term responses to elevated $\mathrm{CO}_{2}$," Ecology, vol. 87, pp. 64-75, 2006. 

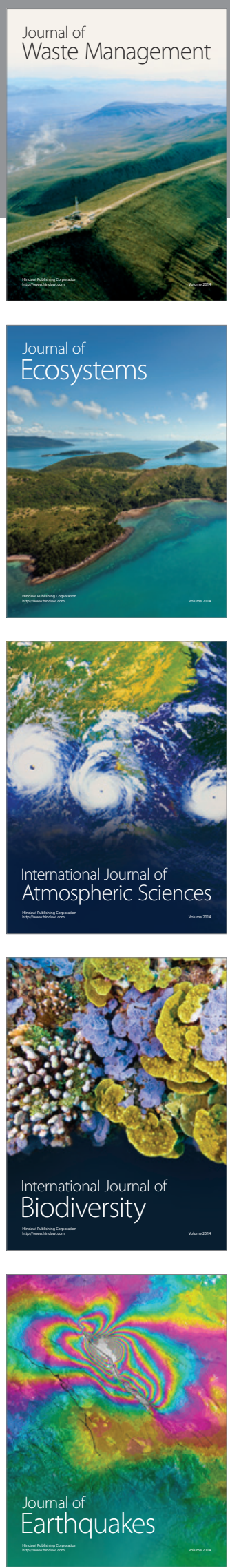
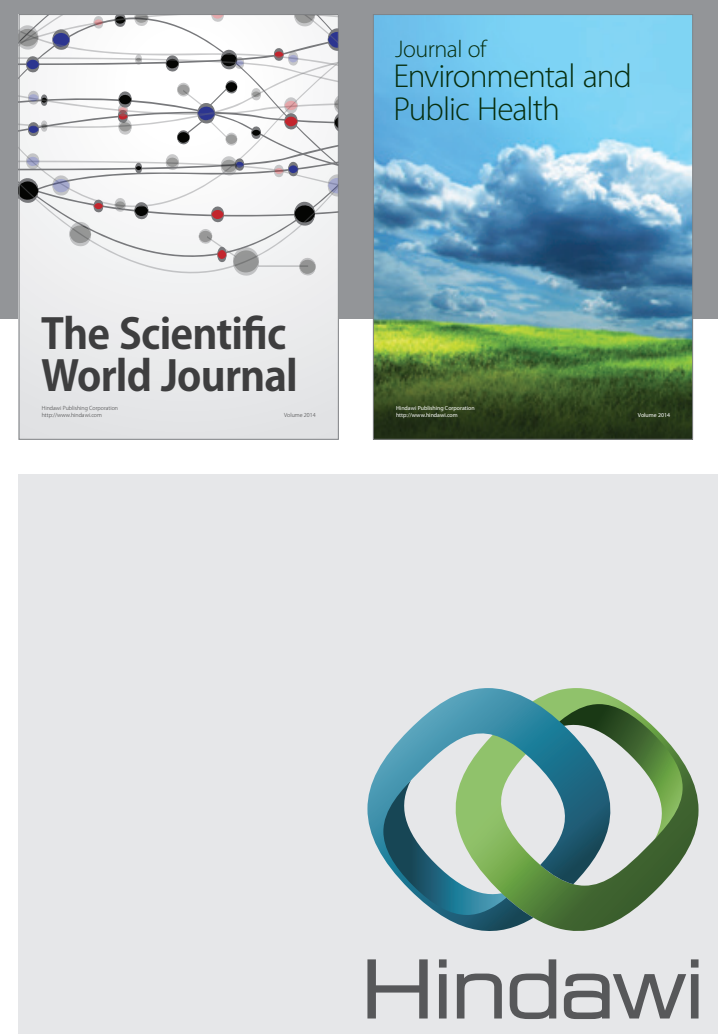

Submit your manuscripts at

http://www.hindawi.com
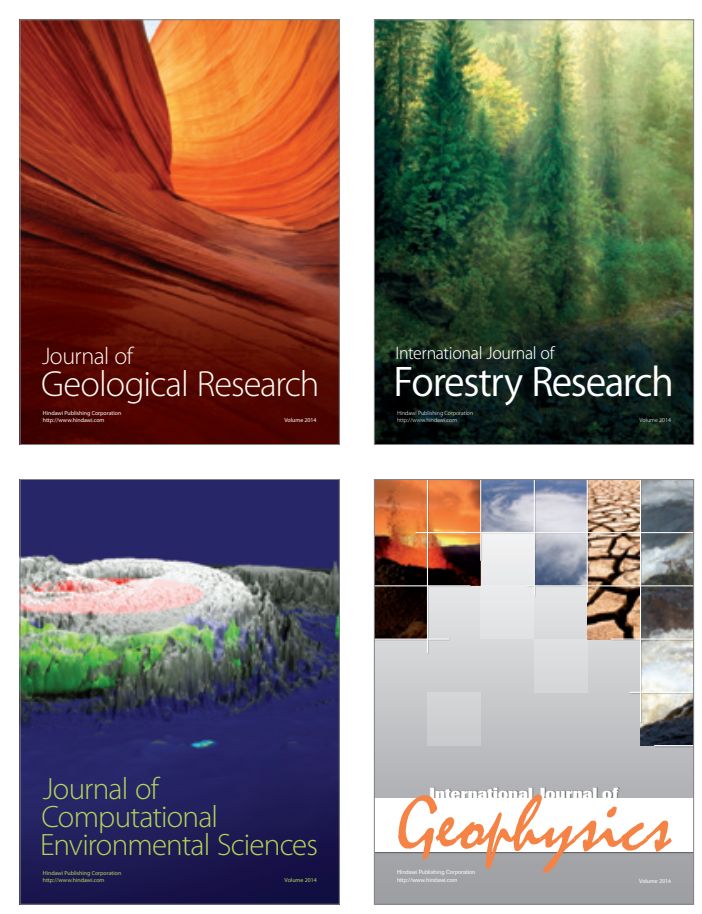
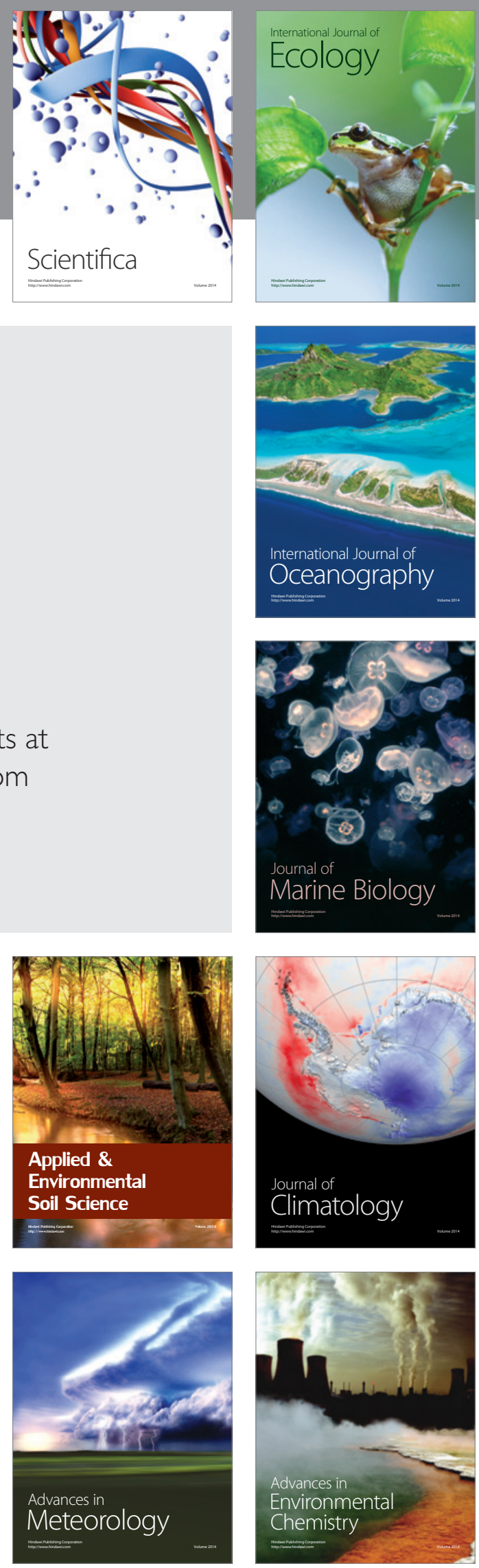